\title{
Relationship between areal hypolimnetic oxygen depletion rate and the trophic state of five lakes in northern Poland
}

\author{
Dariusz Borowiak ${ }^{1}$, Kamil Nowiński ${ }^{2}$, Jacek Barańczuk ${ }^{1}$, \\ Włodzimierz Marszelewski ${ }^{3}$, Rajmund Skowron ${ }^{3}$, Adam Solarczyk ${ }^{3}$
}

\author{
${ }^{1}$ Department of Limnology, University of Gdańsk, Bażyńskiego 4, 80-952 Gdańsk, Poland; e-mail: geodb@univ.gda.pl \\ ${ }^{2}$ Department of Lakelands Geography, University of Gdańsk, Bażyńskiego 4, 80-952 Gdańsk, Poland; e-mail: geokamil@univ.gda.pl \\ ${ }^{3}$ Department of Hydrology and Water Management, Nicolaus Copernicus University, Gagarina 9, 87-100 Toruń, Poland; \\ e-mail:marszel@umk.pl
}

\begin{abstract}
The oxygen content in a lake is a fundamental factor in lake ecology. In stratified lakes, deep waters are isolated from the atmosphere for several months during the summer; therefore, oxygen (substantially consumed by biological and chemical processes at this time) cannot be replaced before the autumnal mixing period. Hypolimnetic oxygen depletion has been considered an indicator of lake productivity since the early twentieth century. Many recent studies have been in opposition to this view by showing that the areal hypolimnetic oxygen depletion rate (AHOD) is poorly correlated with seston biomass and/or phosphorus concentration. The objective of this study is to show relationships between the mean values of total phosphorus (TP), total nitrogen (TN), chlorophyll $a$, and water transparency (Secchi disk depth, SDD) during the thermal stratification formation period and the AHOD rate. Hypolimnetic oxygen conditions in five dimictic lakes in northern Poland were examined in 2009 and 2010. Two of them were studied in the previous year. Monthly oxygen profiles taken from April to August, midsummer temperature profiles, and morphological data of the lakes were used to determine the AHOD rate. Standard water quality parameters such as concentrations of chlorophyll $a$, TP, and TN, as well as water transparency measured at the same time were used to calculate the trophic state indices (TSI) according to the Carlson-type formulas. On the basis of the collected data it is shown that AHOD is highly correlated with the TSI value for chlorophyll $a$, and poorly correlated with the TSI values for water transparency and phosphorus content. The best correlation between AHOD and TSI has been found for chlorophyll $a\left(\mathrm{r}^{2}=0.702 ; \mathrm{p}<0.001\right)$, as well as for overall TSI, determined by averaging separate component indices $\left(\mathrm{r}^{2}=0.826 ; \mathrm{p}<0.000\right)$. No correlation was found between AHOD and total nitrogen concentration. The research also confirmed previous observations, which pointed to a significant role of the hypolimnion depth in increasing oxygen deficits.
\end{abstract}

Key words: water quality, eutrophication, lake ecology, oxygen consumption, summer stagnation

\section{Introduction}

Lake oxygen content is one of the basic factors affecting lake ecology. A variety of aqueous organisms considered to be aerobes limit their reproductive activity and may even suffer physical elimination in the face of oxygen deficits or a complete lack of oxygen in water. At the same time, lake water oxygen levels determine the number and vertical distribution of many species. Furthermore, oxygen content in water is a control factor of the redox state of other important elements in a lake ecosystem, such as carbon, nitrogen, phosphorus, iron, and manganese. Consequently, oxygen levels determine conditions of their circulation in a water body.
In the stratified lakes, the deep and virtually devoid of sunlight hypolimnion waters remain cut off from the atmosphere throughout summer months. The oxygen in the layer used up in biological and chemical processes cannot be restored before the autumn circulation period begins. The quantity of oxygen remaining in the hypolimnion at the end of the summer stagnation period depends both on the quantity of oxygen present prior to the onset of lake stratification, and the rate of influx of the matter undergoing oxidation (mainly organic matter) from the lake's upper layers, and the quantity of such matter already present in the hypolimnion.

Research published in the early twentieth century connected the subject of hypolimnetic oxygen 
depletion to biological production and lake trophic state (Birge and Juday 1911; Thieneman 1926, 1928; Strøm 1931; Hutchinson 1938, 1957; Mortimer 1941; McColl 1970). However, later research has shown that biological production explains less than fifty percent of the differences in the rate of areal hypolimnetic oxygen depletion (AHOD) (Cornett and Rigler 1979, 1980; Rutherford 1982).

This is the result of the oversight of the role of the hypolimnion temperature, which affects decomposition rate of microbiologic matter turning into sediment (Charlton 1980; Rosa and Burns 1987), as well as the oversight of the role of the hypolimnion thickness, which affects the effectiveness of oxidation - a process that intensifies with increasing hypolimnion thickness (Charlton 1980; Cornett and Rigler 1980).

In light of the conflicting views found in the literature on the role of different trophic factors in the observed oxygen depletion rates in the hypolimnion, the study attempts to assess the impact of total phosphorus, total nitrogen, chlorophyll $a$, and water transparency on the areal hypolimnetic oxygen depletion rate $(\mathrm{AHOD})$ in the lakes of northern Poland.

\section{Study area}

Five dimictic lakes located in northern and northeastern Poland were selected for the research purposes. The morphometric parameters of the lakes' basins, smaller areas of the water tables and the maximum depths above $19 \mathrm{~m}$ (Table 1, Fig. 1), cause that these lakes naturally tend to maintain permanent summer stratification, which normally lasts from end of April to late August or mid-September. At its peak stage, the maximum hypolimnion thickness in these lakes ranges from 10-11 meters (Lake Kępno) to over

Table 1. Morphometric characteristics of the studied lakes

\begin{tabular}{|c|c|c|c|c|c|}
\hline \multirow{2}{*}{ Parameter } & \multicolumn{5}{|c|}{ Lake } \\
\hline & Białe & Kępno & Łazduny & Raduńskie Górne & Szurpiły \\
\hline Area, $A_{\text {(ha) }}$ & 51.2 & 65.0 & 10.6 & 387.2 & 80.9 \\
\hline Volume, $V\left(\right.$ dam $\left.^{3}\right)$ & $2,508.8$ & $4,223.6$ & 964.6 & $60,158.7$ & $8,168.0$ \\
\hline Maximum depth, $Z_{m}(\mathrm{~m})$ & 31.0 & 19.0 & 22.4 & 43.0 & 46.2 \\
\hline Mean depth, $\bar{Z}_{(\mathrm{m})}$ & 4.9 & 6.4 & 9.1 & 15.5 & 10.0 \\
\hline Depth ratio $\left(\bar{Z} / Z_{m}\right)$ & 0.16 & 0.34 & 0.41 & 0.36 & 0.22 \\
\hline Relative depth*, $Z_{r}(\%)$ & 3.84 & 2.09 & 6.10 & 1.94 & 4.55 \\
\hline
\end{tabular}

* Relative depth is the ratio of maximum depth and mean lake diameter, $Z_{r}=0.886 Z_{m} / \sqrt{A}$

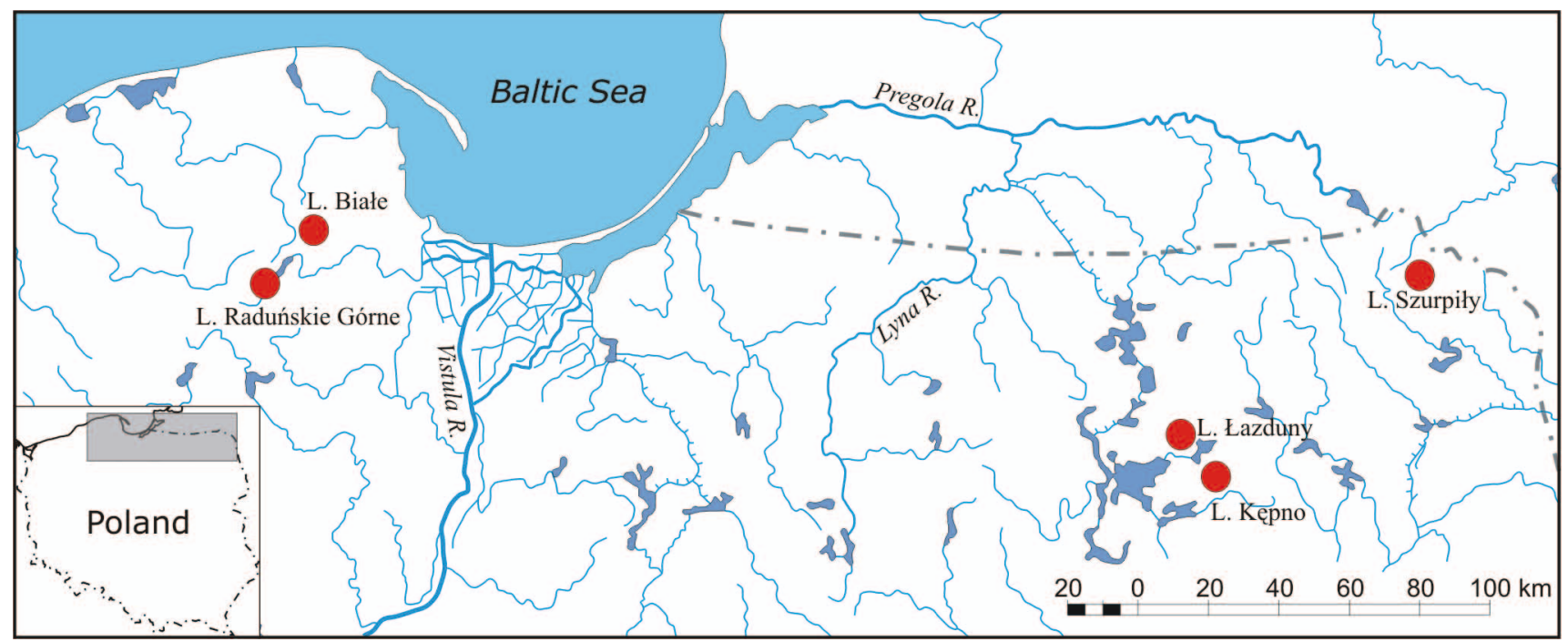

Fig. 1. Location of studied lakes (circles) on a map of Polish geographic regions 
30 meters (lakes: Raduńskie Górne and Szurpiły). The hypolimnion layer makes up between 2\% (Lake Kępno) and 40\% (lakes: Raduńskie Górne, Szurpiły, and Lazduny) of the lakes' total volume. In Lake Białe, the hypolimnion constitutes about $25 \%$ of the lake's total volume.

\section{Materials and methods}

The limnological data used in the study were acquired between April and August of 2009 and 2010. The measurements were normally performed once a month. In the case of two of the lakes (Kępno, Raduńskie Górne), data from 2008 covering the same time period were also analyzed.

Water temperature, dissolved oxygen content, and chlorophyll $a$ concentration were measured at the deepest place in each lake. Thermal and oxygen profiles were generated using a multi-parametric YSI 6820-M (YSI Inc., USA) probe at one-meter intervals from the lake surface to the bottom. A Mini-Tracka II fluorimeter (Chelsea Instruments Ltd., UK) was used to measure chlorophyll $a$ concentration at one-meter intervals up to the depth of $15 \mathrm{~m}$. The Secchi disk depth (SDD) was used to determine water transparency. Water samples for total phosphorus (TP) and total nitrogen (TN) analysis were obtained at a standard depth of 1 meter.

The location of the hypolimnion was estimated graphically using thermal profiles from July and $\mathrm{Au}-$ gust. The upper boundary of the hypolimnion was determined at the point of the intersection of the trend lines fitted to the thermal profiles running through the metalimnion and the upper hypolimnion (Wetzel 1983).

The areal hypolimnetic oxygen depletion rate was determined from the inclination of the regression line of the mean hypolimnion oxygen content per unit area (the upper surface of the hypolimnion) with respect to time (Lasenby 1975) (Fig. 2).

The concentration of chlorophyll $a$ was determined based on profile measurements as an average value for a column of water found within the trophogenic zone (the photic zone).

Total phosphorus was determined spectrophotometrically using the phosphomolybdenum blue method (PMB) after the mineralization of the sample, which involved converting phosphorus-bearing compounds in the collected water samples into orthophosphate and. Total nitrogen was also determined spectrophotometrically using the reaction between nitrate ions and a derivative of benzoic acid in the presence of concentrated sulfuric acid. This reaction produces a dark red nitro compound, which is then analyzed photometrically. As this method is used to mark nitrate ions, the organic and inorganic nitrogenbearing compounds had to be reduced to nitrate first, using a strong persulfate oxidizing agent (the Koroleff Method). Nutrients were analyzed using non-filtered water samples.

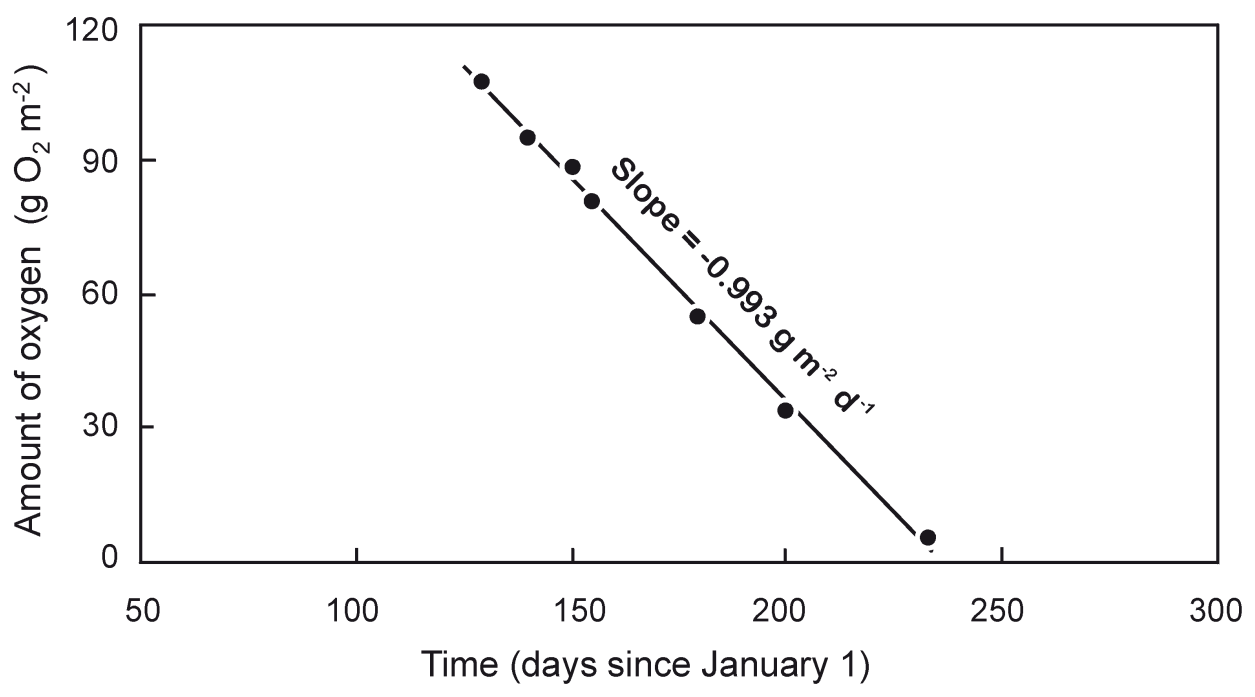

Fig. 2. Average dissolved oxygen content in the hypolimnion per unit area of the upper boundary of the hypolimnion following thermal stratification (Lake Raduńskie Górne, 2009) 
The mean values of selected water quality parameters (Chl $a$, SDD, TP, TN) for the pre-stratification and thermal stratification periods (April - August) were converted to the Carlson-type trophic indices (Carlson 1977; Kratzer and Brezonik 1981).

\section{Results}

The trophic state indices and the water trophic parameters used to calculate them suggest that the lakes studied are good examples of mesotrophic lakes $(40<\mathrm{TSI}<60)($ Table 2$)$.

The regression analysis shows that the strongest statistical correlation between qualitative characteristics exists between AHOD and average chlorophyll $a$ concentration in the trophogenic layer (Fig. 3). The trophic state index based on chlorophyll $a$ (TSI(CHL)) explains $70 \%$ of inter-lake variability in the areal hypolimnetic oxygen depletion rate at a significance level of $\mathrm{p}<0.001$. This relationship may indicate that the principal form of matter undergoing oxidation in the hypolimnion layer is dead organic matter precipitating out of the trophogenic zone. The oxidation of compounds that have been stirred from the lake bottom sediments and re-suspended in the water plays a smaller role.
The relationship between AHOD and the Secchi disk depth also turned out statistically significant $(\mathrm{p}<0.016)$ (Fig. 4). The independently analyzed TSI(SDD) index explains over $45 \%$ of observed differences in AHOD.

The concentration of total phosphorus (TSI(TP)) has also a limited impact upon oxygen depletion in the hypolimnion layer of the studied lakes (Fig. 5). The same is true of the mean depth of the hypolimnion layer $\left(\bar{z}_{h}\right)$. Both the characteristics may explain the inter-lake differences in AHOD in the 47\% to $51 \%$ range, respectively. However, the statistical significance of these relationships was quite small $(\mathrm{p}<0.010$ 0.020). This points to the existence of an observable trend of AHOD to increase along with increasing TP concentration and the mean hypolimnion depth. Yet, both relationships are not very useful for forecasting purposes.

No statistically significant relationships were identified between AHOD and total nitrogen concentration TSI(TN) $\left(\mathrm{r}^{2}=0.096, \mathrm{p}<0.35\right)$. The lack of a clear relationship between AHOD and total nitrogen concentration and the strong relationship between AHOD and TSI $(\mathrm{CHL})$ are indications that nitrogen is not a limiting agent in primary production in the studied lakes.

Table 2. Ecological characteristics of the water column listed as the mean values for the time period from April to August (2008-2010)

\begin{tabular}{|c|c|c|c|c|c|c|c|c|c|c|c|c|}
\hline \multirow{3}{*}{ Parameter } & \multicolumn{12}{|c|}{ Lake } \\
\hline & \multicolumn{2}{|c|}{ Białe } & \multicolumn{3}{|c|}{ Kępno } & \multicolumn{2}{|c|}{ Łazduny } & \multicolumn{3}{|c|}{ Raduńskie Górne } & \multicolumn{2}{|c|}{ Szurpiły } \\
\hline & 2009 & 2010 & 2008 & 2009 & 2010 & 2009 & 2010 & 2008 & 2009 & 2010 & 2009 & 2010 \\
\hline Total phosphorus, TP $\left(\mu \mathrm{g} \mathrm{dm}^{-3}\right)$ & 11 & 14 & 15 & 10 & 16 & 14 & 16 & - & 17 & 32 & 21 & 27 \\
\hline Total nitrogen, $\mathrm{TN}\left(\mathrm{mg} \mathrm{dm}^{-3}\right)$ & 0.64 & 0.55 & 0.69 & 0.58 & 0.59 & 0.29 & 0.32 & - & 0.63 & 0.80 & 0.28 & 0.24 \\
\hline Chlorophyll a, $\mathrm{CHL}\left(\mu \mathrm{g} \mathrm{dm}^{-3}\right)$ & 9.3 & 8.5 & 16.9 & 10.3 & 11.4 & 6.7 & 11.4 & 21.9 & 17.0 & 14.5 & 11.3 & 15.0 \\
\hline Secchi disk depth, SDD (m) & 4.7 & 4.9 & 2.7 & 3.6 & 2.9 & 4.3 & 4.0 & 2.6 & 3.0 & 3.2 & 3.0 & 2.9 \\
\hline TSI (TP) (dimensionless) & 39 & 42 & 43 & 37 & 44 & 42 & 44 & - & 45 & 54 & 48 & 52 \\
\hline TSI (TN) (dimensionless) & 48 & 46 & 49 & 47 & 47 & 37 & 38 & - & 48 & 51 & 36 & 34 \\
\hline TSI (CHL) (dimensionless) & 52 & 52 & 58 & 53 & 54 & 49 & 54 & 61 & 58 & 57 & 54 & 57 \\
\hline TSI (SDD) (dimensionless) & 38 & 37 & 46 & 42 & 45 & 39 & 40 & 46 & 44 & 43 & 44 & 45 \\
\hline Mean TSI (dimensionless) & 44 & 44 & 49 & 45 & 48 & 42 & 44 & 54 & 49 & 51 & 46 & 47 \\
\hline Mean hypolimnion depth, $\bar{z}_{h}(\mathrm{~m})$ & 5.3 & 5.3 & 3.6 & 3.2 & 3.6 & 6.9 & 7.0 & 11.4 & 10.9 & 11.4 & 9.1 & 9.2 \\
\hline Maximum hypolimnion depth, $z_{h}(\mathrm{~m})$ & 25.5 & 26.0 & 10.9 & 10.2 & 11.1 & 14.4 & 14.7 & 33.4 & 30.7 & 33.6 & 37.0 & 37.3 \\
\hline $\operatorname{AHOD}\left(\mathrm{g} \mathrm{m}^{-2} \mathrm{~d}^{-1}\right)$ & 0.286 & 0.414 & 0.774 & 0.268 & 0.297 & 0.147 & 0.080 & 1.750 & 0.993 & 1.088 & 0.712 & 0.721 \\
\hline
\end{tabular}




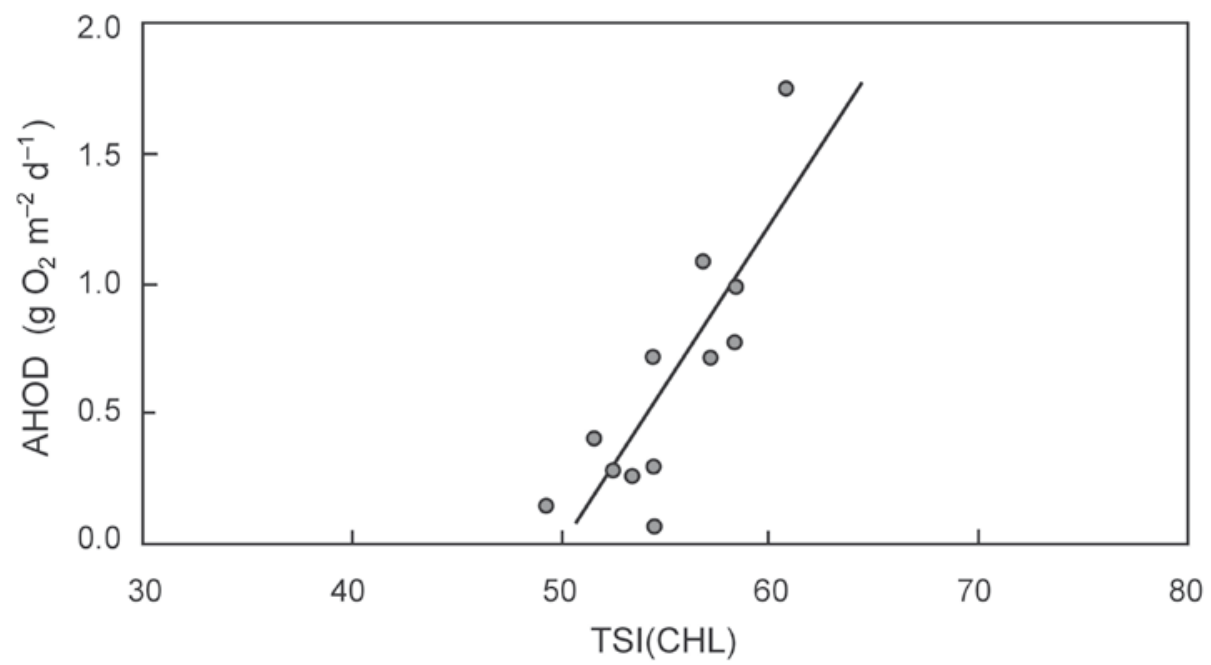

Fig. 3. Relationship between the mean value of the trophic state index for chlorophyll $a$ (TSI(CHL)) during the period of thermal stratification and $\operatorname{AHOD}\left(\mathrm{n}=12, \mathrm{r}^{2}=0.702, \mathrm{p}<0.001\right)$

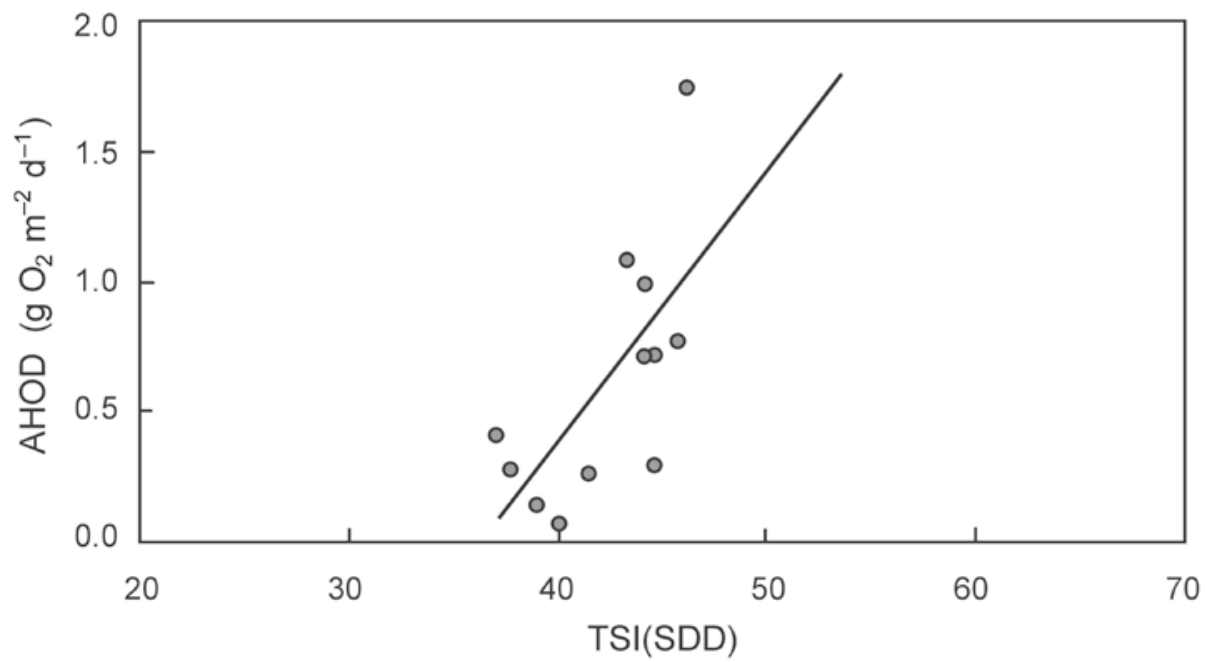

Fig. 4. Relationship between the mean value of the trophic state index for the Secchi disk depth (TSI(SDD)) during the period of thermal stratification and AHOD $\left(n=12, r^{2}=0.457, p<0.016\right)$

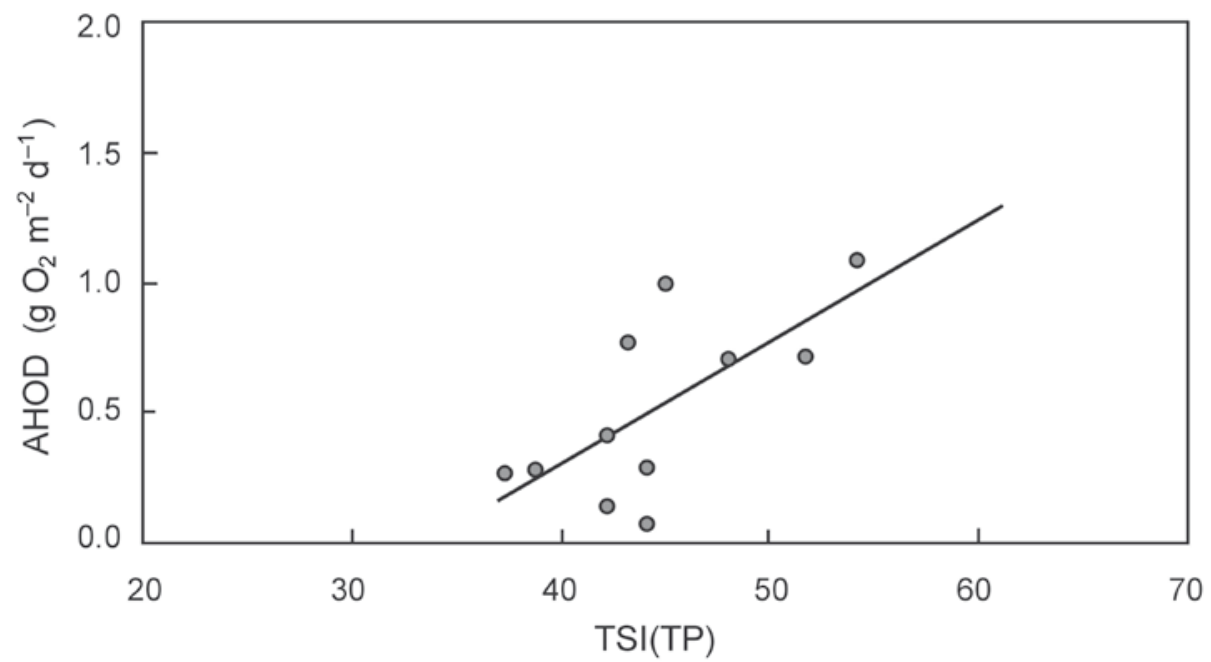

Fig. 5. Relationship between the mean value of the trophic state index for total phosphorus (TSI(TP)) during the period of thermal stratification and AHOD $\left(n=11, r^{2}=0.472, p<0.020\right)$ 
Though the different trophic state indices exhibited different levels of correlation with the oxygen depletion rate for the hypolimnion layer, the mean trophic state index (TSI) appeared to be the best predictor $\left(r^{2}=0.826, p<0.000\right)$ (Fig. 6). This index is an average of all the component indices produced for this study.
The multiple regression analysis confirmed the significance of the role of the hypolimnion depth as a powerful factor in total oxygen consumption in the hypolimnion layer. The AHOD prognostic models based upon the mean values of the trophic state index (TSI) and the hypolimnion depth (mean $-\bar{z}_{h}$, and maximum $-z_{h}$ ) as independent variables are the following:

$$
\begin{aligned}
& \text { AHOD }\left(g \mathrm{O}_{2} m^{-2} d^{-1}\right)=0.105 T S I+0.049 \bar{z}_{h}-4.65 \quad\left(\mathrm{r}^{2}=0.897, \mathrm{p}<0.0001\right), \\
& \text { AHOD }\left(g \mathrm{O}_{2} m^{-2} d^{-1}\right)=0.111 T S I+0.014 z_{h}-4.93 \quad\left(\mathrm{r}^{2}=0.907, \mathrm{p}<0.0001\right) .
\end{aligned}
$$

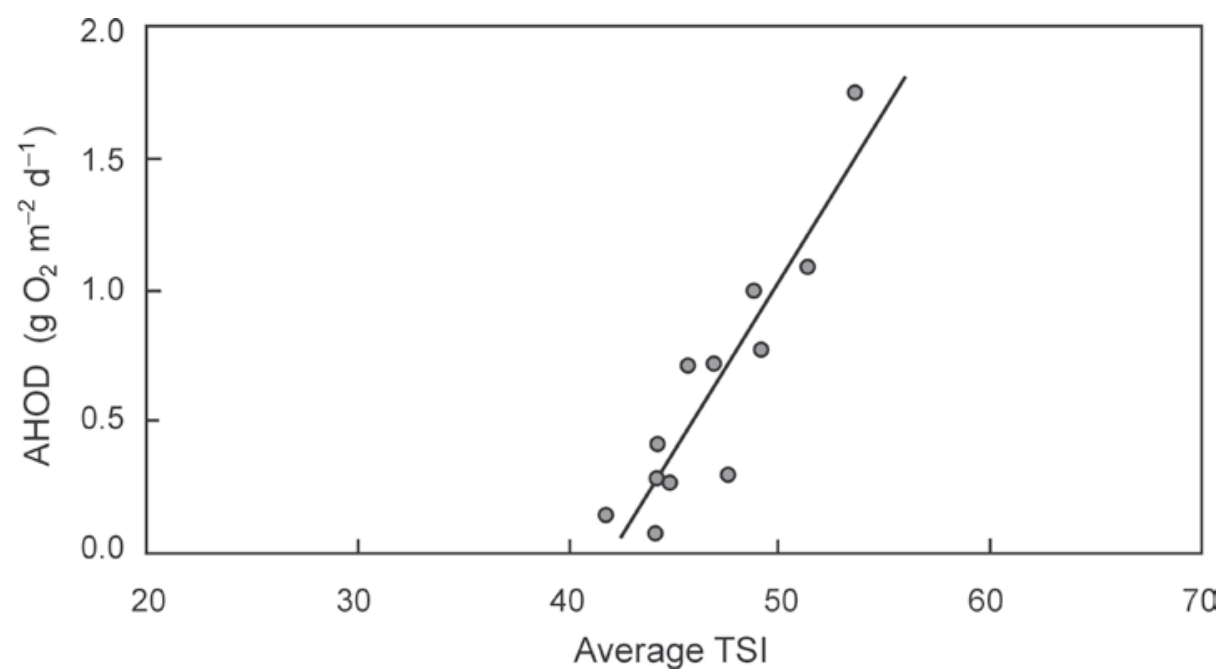

Fig. 6. Relationship between the mean value of the trophic state index for overall TSI (determined by averaging component indices) during the period of thermal stratification and AHOD $\left(n=12, r^{2}=0.826, p<0.0001\right)$

\section{Discussion}

The analysis of selected water quality parameters for five mesotrophic lakes in northern and northeastern Poland as well as the assessment of the influence of these parameters upon the rate of oxygen depletion in the hypolimnion layer have produced satisfactory results. The principal factors affecting the rate of hypolimnetic oxygen consumption were shown to be the mean chlorophyll $a$ concentration in the trophogenic zone and the depth of the Secchi disk.

The role of biological production has been frequently identified as the key driver of hypolimnetic oxygen depletion. Yet, earlier research publications on the larger groups of lakes pointed out that this vari- able explains less than 50\% of observed AHOD variability (Cornett and Rigler 1979, 1980). In the case of a smaller group of lakes - and more importantly, a group of lakes more homogeneous in terms of trophic state - the TSI(CHL)-AHOD relationship is more significant, with changes in chlorophyll $a$ concentration explaining over $70 \%$ of the inter-lake differences in AHOD.

Some of the possible explanations for this inconsistency may include the fact that the lakes studied (except for Lake Kępno) possess hypolimnion layers of a similar depth (8.7 $\pm 2.5 \mathrm{~m}$; hence, similar oxidation capabilities) and no significant changes in the mean hypolimnion temperature were detected in the lakes during the period of stratification. 
The studied lakes can be classified as mesotrophic based on virtually all the available water quality parameters and are characterized by an AHOD range of 0.15-1.75 $\mathrm{g} \mathrm{O}_{2} \mathrm{~m}^{-2} \mathrm{~d}^{-1}$ (Table 2). The AHOD range determined for mesotrophic lakes by Hutchinson (1938) and Mortimer (1941) - 0.33-0.50 and 0.25-0.55 $\mathrm{g} \mathrm{O}_{2} \mathrm{~m}^{-2} \mathrm{~d}^{-1}$, respectively - clearly does not match the AHOD range determined for the five lakes analyzed in northern Poland. Even when the TSI $(x)$ criteria used for mesotrophic lakes are more rigorous (e.g. $\operatorname{TSI}(x) \in\langle 40,50\rangle)$ than those in this study, the results still suggest that the AHOD range for mesotrophic lakes should be 0.15 to $0.99 \mathrm{~g} \mathrm{O}_{2} \mathrm{~m}^{-2} \mathrm{~d}^{-1}$.

The significance of the relationship between AHOD and the Secchi disk depth (SDD) has been shown in other publications. Lasenby (1975) identified SDD as the factor best correlated with oxygen depletion in the hypolimnion relative to other commonly used indicators of lake trophic state (e.g. seston biomass).

The significant explanatory value of both the above mentioned indices of the lake trophic state in the process of estimating the inter-lake AHOD variability clearly demonstrates the need for such explanatory variables in the prognostic models. The variables of this type should be either averaged for the entire trophogenic zone (chlorophyll $a$ ) or should at least be indirectly representative of the entire trophogenic zone (Secchi disk depth).

The role of phosphorus in the TSI(TP)-AHOD relationship has also been confirmed, as did Cornett and Rigler (1980). The relationship between these two variables indicates that it can only explain about $47 \%$ of the observed AHOD variability.

The research also confirmed earlier observations, which pointed to a significant role of the hypolimnion depth in the oxygen depletion rate (Welch et al. 1976; Charlton 1980). The importance of the role of the mean hypolimnion depth is underscored by its readable relationship with AHOD and the increase in the prognostic power of AHOD when analyzed using multiple regression, where the variables are the mean trophic state index (TSI) and the mean hypolimnion depth.

AHOD, being the standardized relative to the mean hypolimnion depth $\left(\bar{z}_{h}\right)$ volumetric hypolimnetic oxygen depletion rate $\left(A H O D=V H O D \times \bar{z}_{h}\right)$ should be independent of the so-called dilution effect of the settling material (Strøm 1931; Hutchinson 1938, 1957). In spite of this, AHOD is not completely inde- pendent of the influence of the hypolimnion depth on the rate of oxygen depletion in this layer during the summer stratification period. The lakes with deeper hypolimnion layers provide a longer sedimentation pathway, which creates favorable conditions for complete oxidation of matter undergoing sedimentation (Charlton 1980; Cornett and Rigler 1980).

\section{Acknowledgements}

The research presented in this study was financially supported by the Ministry of Science and Higher Education of the Republic of Poland within the frames of the Project No. N N306 354836.

\section{References}

Birge E.A., Juday C., 1911, The inland lakes of Wisconsin. The dissolved gases of the water and their biological significance, Wis. Nat. Hist. Surv. Bull. 22: 1-139.

Carlson R.E., 1977, A trophic state index for lakes, Limnol. Oceanogr. 22: 361-369.

Charlton M.N., 1980, Hypolimnion oxygen consumption in lakes: discussion of productivity and morphometry effects, Can. J. Fish. Aquat. Sci. 37: 1531-1539.

Cornett R.J., Rigler F.H., 1979, Hypolimnetic oxygen deficits: their prediction and interpretation, Science 205: 580-581.

Cornett R.J., Rigler F.H., 1980, The areal hypolimnetic oxygen deficit: an empirical test of the model, Limnol. Oceanogr. 25: 672-679.

Hutchinson G.E., 1938, On the relation between the oxygen deficyt and the productivity and typology of lakes, Int. Rev. Hydrobiol. 36: 336-355.

Hutchinson G.E., 1957, A treatise on limnology. I. Geography, physics, and chemistry, Wiley, New York, p. 1015.

Kondracki J., 2002, Geografia regionalna Polski (Regional geography of Poland), Wyd. Nauk. PWN, Warszawa, p. 440 (in Polish).

Kratzer C.R., Brezonik P.L., 1981, A Carlson-type trophic state index for Nitrogen in Florida lakes, Water Res. Bull. 17: 713-715.

Lasenby D.C., 1975, Development of oxygen deficits in 14 southern Ontario lakes, Limnol. Oceanol. 20: 993-999.

McColl R.H.S., 1972, Chemistry and trophic status of seven New Zealand lakes, New Zeal. J. Mar. Fresh. 6: 399-447.

Mortimer C.H., 1941, The exchange of dissolved substances between mud and water (Parts I and II), J. Ecol. 29: 280329.

Rosa F., Burns N.M., 1987, Lake Erie central basin oxygen depletion changes from 1929 to 1980, J. Great Lakes Res. 13: 684-696.

Rutherford J.C., 1982, Deoxygenation rates in twelve New Zealand lakes. In: Aquatic oxygen seminar procedings, 
Hamilton, November 1980, Water and Soil Miscellaneous Publication 29. Ministry of Works and Development, Wellington: 179-185.

Strøm K.M., 1931, Fetovatn: a physiographic and biological study of mountain lake, Arch. Hydrobiol. 22: 491-536.

Thienemann A., 1926, Der Nahrungskreislauf im Wasser, Verh. Dtsch. Zool. Ges. 2: 29-79.
Thienemann A., 1928, Der Sauerstoff im eutrophen und oligotrophen Seen. Ein Beitrag zur Seetypenlehre. Die Binnengewässer 4. Schweizerbartsche Verlagsbuchhandlung, Stuttgart, p. 175.

Welch H.E, Dillon P.J., Sreedharan A., 1976, Factors affecting winter respiration in Ontario lakes, J. Fish. Res. Bd. Can. 33: 1809-1815.

Wetzel R.G., 1983, Limnology, Saunders Coll., Philadelphia, p. 860. 